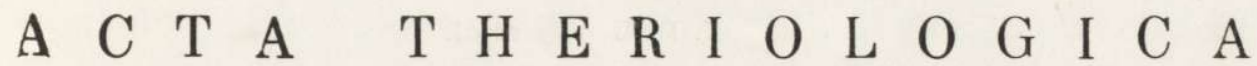

VOL. XV, 12: 179-190.

August, 1971.

John B. GENTRY, Frank B. GOLLEY \& Michael H. SM ITH

\section{Yearly Fluctuations in Small Mammal Populations in a Southeastern United States Hardwood Forest*}

[With 3 Tables \& 3 Fig.]

A 5.8 hectare grid, consisting of 256 stations spaced 15 meters apart, was laid out in a mature cove hardwood forest near Aiken, South Carolina, USA. Snap traps were used to remove animals from the grid. The grid was trapped once each year from 1967-1970. Emphasis was placed upon population levels, changes in species composition and habitat utilization of the small mammals. Also considered were the effects of various environmental and treatment variables upon the final trapping results. Population levels declined during the study. Species composition did not remain the same over the four year period. Prebaiting resulted in different removal rates. Weather changes also influenced removal rates.

\section{INTRODUCTION}

One major factor which can affect the results of small mammal trapping studies is time. We usually fail to recognize how fast environmental and population parameters can change over time. Several investigators (Hayne, 1949; Sidorowicz, 1960; Calhoun, 1964; Gentry, Golley \& McGinnis, 1966; Grodziński, Pucek \& Ryszkowski, 1966; Wiegert \& Mayenschein, 1966; Gentry, Golley \& Smith, 1968; Buchalczyk \& Pucek, 1968; Pucek, 1969; Smith, Kaufman, Jones, Gentry \& $\mathrm{Smith}$, 1971) have pointed out that such factors as season, weather, type of trap, probability of capture, movement, mortality, reproduction, and intra and interspecific interactions may affect trapping results. Many of these factors may prove difficult, sometimes impossible, to measure. Thus, assumptions are made that certain variables remain constant during the study. Most investigators will readily admit that most of such

* This study was carried out under contract AT(38-1)-310 between the University of Georgia and the United States Atomic Energy Commision. 
assumptions are rarely met in nature. These assumptions may even be more critical if one makes several isolated observations and attempts to make direct comparisons between them.

At the Savannah River Ecology Laboratory (SREL), we have collected data on small mammal populations through the extensive use of removal trapping. This paper reports on one trapping study in which changes in a small mammal population are compared over a four year period. The main objective of this report is to emphasize how treatment, environmental, and population parameters may influence the results of small mammal trapping studies.

\section{METHODS}

A 5.8 ha grid, consisting of 256 stations spaced $15 \mathrm{~m}$ apart, was laid out in a mature cove hardwood forest. Two mouse snap-traps (one Victor and one Museum Special) were placed at each station. The area was trapped once each summer between 1967-70 (Table 1). The traps were prebaited with peanut butter for five days for the 1967 and 1968 periods. The prebaiting treatment was eliminated from the 1969 and 1970 trapping periods. During the small mammal removal phase of the study, the traps were checked, rebaited and reset as necessary each day thereafter. Location of capture, sex, reproductive condition and weight of each animal were recorded. The area was trapped for 27 consecutive days during 1967 and 1970 and 18 consecutive days during 1968 and 1969. All comparisons are made on the basis of an 18-day trapping period unless stated otherwise.

\section{HABITAT DESCRIPTION}

The study area could be divided into three different habitat types. On the drier slopes upland hardwoods covered 2.6 ha $(44.8 \%$ of the total area). This type was dominated by oak (Quercus sp.) and hickory (Carya sp.). Lowland hardwood-swamp forest, located in the flat, damp stream bottom, covered 2.7 ha $(46.6 \%)$ and was dominated by sweet gum (Liquidambar styraciflua), black gum (Nyssa sylvatica), yellow poplar (Liriodendron tulipifera) and lowland oaks (Quercus sp.). Many of the shrubs and trees in the lowland hardwood swamp were covered with vines, which were mostly wild grape (Vitis sp.) and greenbriar (Smilax sp.). A small area of old-field habitat ( 0.5 ha; $8.6 \%$ of the total area), dominated by broomsedge (Andropogon sp.) and scattered second-growth pines (Pinus sp.), extended into the eastern border of the study area.

\section{RESULTS}

The small mammal species captured in the greatest abundance are listed in Table 1. The southeastern shrew, Sorex longirostris B a c h m a n, 1837, was relatively abundant the first year (1967) but declined rapidly by 1968; none were captured in 1970. Captures of the cotton mouse, Peromyscus gossypinus (Le Conte, 1853), the short-tailed shrew, Bla- 
rina brevicauda ( $\mathrm{S}$ a y, 1823), and the golden mouse, Ochrotomys nuttalli ( $\mathrm{H}$ a r l a n, 1832), fluctuated from year to year. The eastern wood rat, Neotoma floridana ( $\mathrm{Ord}$, 1818), was occasionally captured. The wood rat captures were incidental since the traps were too small to provide accurate capture data for this species. Two captures of the least shrew Cryptotis parva (S a y, 1823) were made in the old-field habitat in 1970.

Table 1

Small mammal captures in a southeastern U. S. hardwood forest. Each species is expressed as a per cent of the total number of animals captured during an 18-day period of removal. Numbers in parentheses $=$ number of captures. $(\mathrm{P})=$ prebaited; $(\mathrm{NP})=$ not prebaited.

\begin{tabular}{|c|c|c|c|c|c|c|}
\hline Species & $\begin{array}{c}1967 \\
\text { (Sept.-Oct.) } \\
\text { (P) }\end{array}$ & $\begin{array}{c}1968 \\
\text { (July-Aug.) } \\
\text { (P) }\end{array}$ & $\begin{array}{c}1969 \\
\text { (May-June) } \\
\text { (NP) }\end{array}$ & $\begin{array}{c}1970 \\
\text { (Apr.-May) } \\
\text { (NP) }\end{array}$ & $\begin{array}{l}\text { Mean } \\
\text { per } \\
\text { cent }\end{array}$ & $\begin{array}{l}\text { Total } \\
\text { cap- } \\
\text { tures }\end{array}$ \\
\hline $\begin{array}{l}\text { P. gossypinus } \\
\text { B. brevicauda } \\
\text { O. nuttalli } \\
\text { S. longirostris }\end{array}$ & $\begin{array}{r}22.2(25) \\
52.2(59) \\
8.8(10) \\
16.8(19)\end{array}$ & $\begin{array}{r}33.3(41) \\
26.0(32) \\
38.2(47) \\
2.5(3)\end{array}$ & $\begin{array}{r}24.6(14) \\
45.6(26) \\
28.1(16) \\
1.7(1)\end{array}$ & $\begin{array}{r}29.7(11) \\
18.9(7) \\
51.4(19) \\
0.0(0)\end{array}$ & $\begin{array}{r}27.4 \pm 2.5 \\
35.7 \pm 7.9 \\
31.6 \pm 9.0 \\
5.3 \pm 3.9\end{array}$ & $\begin{array}{r}(91) \\
(124) \\
(92) \\
(23)\end{array}$ \\
\hline Total captures & (113) & (123) & (57) & (37) & - & (330) \\
\hline
\end{tabular}

Table 2

Number of each sex captured during each removal period and all periods combined. $\mathrm{M}$ - male, $\mathrm{F}$ - female

\begin{tabular}{|c|c|c|c|c|c|c|c|c|c|c|}
\hline \multirow{2}{*}{ Species } & \multicolumn{2}{|c|}{1967} & \multicolumn{2}{|c|}{1968} & \multicolumn{2}{|c|}{1969} & \multicolumn{2}{|c|}{1970} & \multirow{2}{*}{\multicolumn{2}{|c|}{ Total }} \\
\hline & M & $\mathrm{F}$ & M & $\mathrm{F}$ & M & $\mathrm{F}$ & M & $\mathrm{F}$ & & \\
\hline P. gossypinus & 16 & 9 & 20 & 19 & 9 & 5 & 7 & 4 & 52 & 37 \\
\hline O. nuttalli & 4 & 6 & 30 & $16^{*}$ & 10 & 6 & 9 & 8 & 53 & $34 *$ \\
\hline B. brevicauda & 11 & $48 * *$ & 17 & 14 & 10 & 16 & 1 & 6 & 39 & $84^{* *}$ \\
\hline S. longirostris & 5 & $14^{*}$ & - & - & 一 & - & - & 一 & 5 & $14^{*}$ \\
\hline
\end{tabular}

** Significantly different from 1:1 ratio at .001 level.

* Significantly different from 1:1 ratio at .05 level.

The number of individuals of each of the three species captured in the greatest numbers varied from year to year (Table 1). In most cases, one species made up a large percentage of the total in a given year. Rarely were the total numbers captured equally distributed among the three species, although 1968 came close in this respect. Over the four trapping periods, $S$. longirostris made up significantly $(\mathrm{P}<.05)$ the least proportion of the populations. Mean proportions of the other three species did not differ from each other $(\mathrm{P}>.05)$. 


\section{Sex Ratios}

There was a tendency to capture more male $P$. gossypinus during each of the trapping periods (Table 2). Significantly fewer female O. nuttalli were captured in 1968 and more female $B$. brevicauda were captured in 1967. For the four combined removal periods, significantly fewer female $O$. nuttalli were captured while more female $B$. brevicauda were captured. In 1967, the only year that sufficient numbers were taken, female $S$. longirostris were captured almost at the rate of $3: 1$ over males.

Table 3

The proportion of animals, by species, captured in two habitat types. Numbers in parentheses represent the number of captures during a given 18-day removal period.

\begin{tabular}{|c|c|c|c|c|c|}
\hline Year & Peromyscus & Ochrotomys & Blarina & Sorex & Total \\
\hline \multicolumn{6}{|c|}{ LOWLAND HARDWOOD FOREST } \\
\hline $\begin{array}{l}1967 \\
1968 \\
1969 \\
1970 \\
\text { Total }\end{array}$ & $\begin{array}{c}48.7(18) \\
46.1(18) \\
85.7(12) \\
75.0(15) \\
(63)\end{array}$ & $\begin{array}{c}100.0(12) \\
47.8(22) \\
68.7(11) \\
72.4(12) \\
(66)\end{array}$ & $\begin{array}{c}78.3(47) \\
56.7(17) \\
76.9(20) \\
55.5(5) \\
(89)\end{array}$ & $\begin{array}{r}90.5(19) \\
100.0(3) \\
100.0(1) \\
0.0(0) \\
(23)\end{array}$ & $\begin{array}{r}(96) \\
(60) \\
(44) \\
(41) \\
(241)\end{array}$ \\
\hline \multicolumn{6}{|c|}{ UPLAND HARWOOD FOREST } \\
\hline $\begin{array}{l}1967 \\
1968 \\
1969 \\
1970 \\
\text { Total }\end{array}$ & $\begin{array}{c}24.3(9) \\
46.1(18) \\
14.3(2) \\
20.0(4) \\
(33)\end{array}$ & $\begin{array}{c}0.0(0) \\
45.6(21) \\
31.3(5) \\
24.1(7) \\
(33)\end{array}$ & $\begin{array}{c}21.7(13) \\
40.0(12) \\
19.3(5) \\
33.3(3) \\
(33)\end{array}$ & 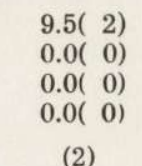 & $\begin{array}{r}(24) \\
(51) \\
(12) \\
(14) \\
(101)\end{array}$ \\
\hline Total & (33) & (33) & (33) & (2) & (10N) \\
\hline
\end{tabular}

\section{Habitat Utilization}

The proportion of animals captured in the lowland hardwood-swamp and the upland hardwood habitat during the 1968 removal period was not far from a 1:1 ratio (Table 3 ). On the other hand, a similar comparison during 1967, 1969 and 1970 was rather close to a $3: 1$ ratio. Although there was some variation from year to year, all four species preferred the lowland hardwood-swamp habitat (Table 3). Ninety-two percent of the S. longirostris were captured in the lowland hardwood-swamp habitat. During the 1967 period of trapping, $100 \%$ of the O. nuttalli were captured in the lowland forest-swamp habitat (Table 3). There was some indication that, when captures were relatively low, $P$. gossypinus and O. nuttalli were captured in the lowland hardwood-swamp habitat in 
relatively greater numbers. This trend was not evident for $B$. brevicauda. In the old-field with scattered pine habitat, only 21 animals were captured during the four removal periods combined. Of these animals, $14(67 \%)$ were $P$. gossypinus.

\section{Removal Rates}

Removal rates, expressed daily as the accumulative proportion of total captures, varied with time and beween species. In 1967, B. brevicauda was removed faster (Fig. 1A) than the other three species captured. $S$. longirostris first appeared in the traps on day 6; O. nuttali showed up for the first time on day 9. Weather conditions remained relatively constant during the 1967 trapping period.

In 1968, each species was removed at about the same rate (Fig. 1B). In 1969, P. gossypinus was removed faster than the other two species (Fig. 1C). Unlike 1967 and 1968, traps were not prebaited during the 1969 period.

Again, in 1970 (Fig. 1D) there were wide differences in removal rates. No animals were captured on the first day of trapping. $P$. gossypinus showed up on day 2, O. nuttalli on day 4, and B. brevicauda on day 13 . A marked weather charge (cloudy with rain) took place between the 12 th and 13th days. Cloudy weather with showers continued until day 15 . Only $27 \%$ of the total number captured by day 18 were removed by day 12 .

The study area was trapped for a total of 27 days during 1967 and 1970. Even though the probability of capture for each species varied widely in 1967 (Fig. 2A; prebaited), the removal curve for combined species indicates a uniform removal rate. The curve for combined species for 1970 (Fig. 2A; not prebaited) reflects a slower and more variable removal rate.

The removal rates for combined species captured in 1968 (prebaited) and 1969 (not prebaited) are compared in Fig. 2B. Animals were removed at a faster rate following prebaiting. Small mammals removed during the 1967 and 1968 trapping periods were removed at a faster rate than those removed during the 1969 and 1970 periods (Fig. 3).

Other factors which may have influenced the trapping results may be summarized as follows:

1. Season: The 1967 trapping took place during the fall (September-October) while the 1970 trapping took place during late spring (April May; Table 1).

2. Numbers: Relative numbers of small mammals were lower in 1970 than 1967. This fact was substantiated by other studies taking place 

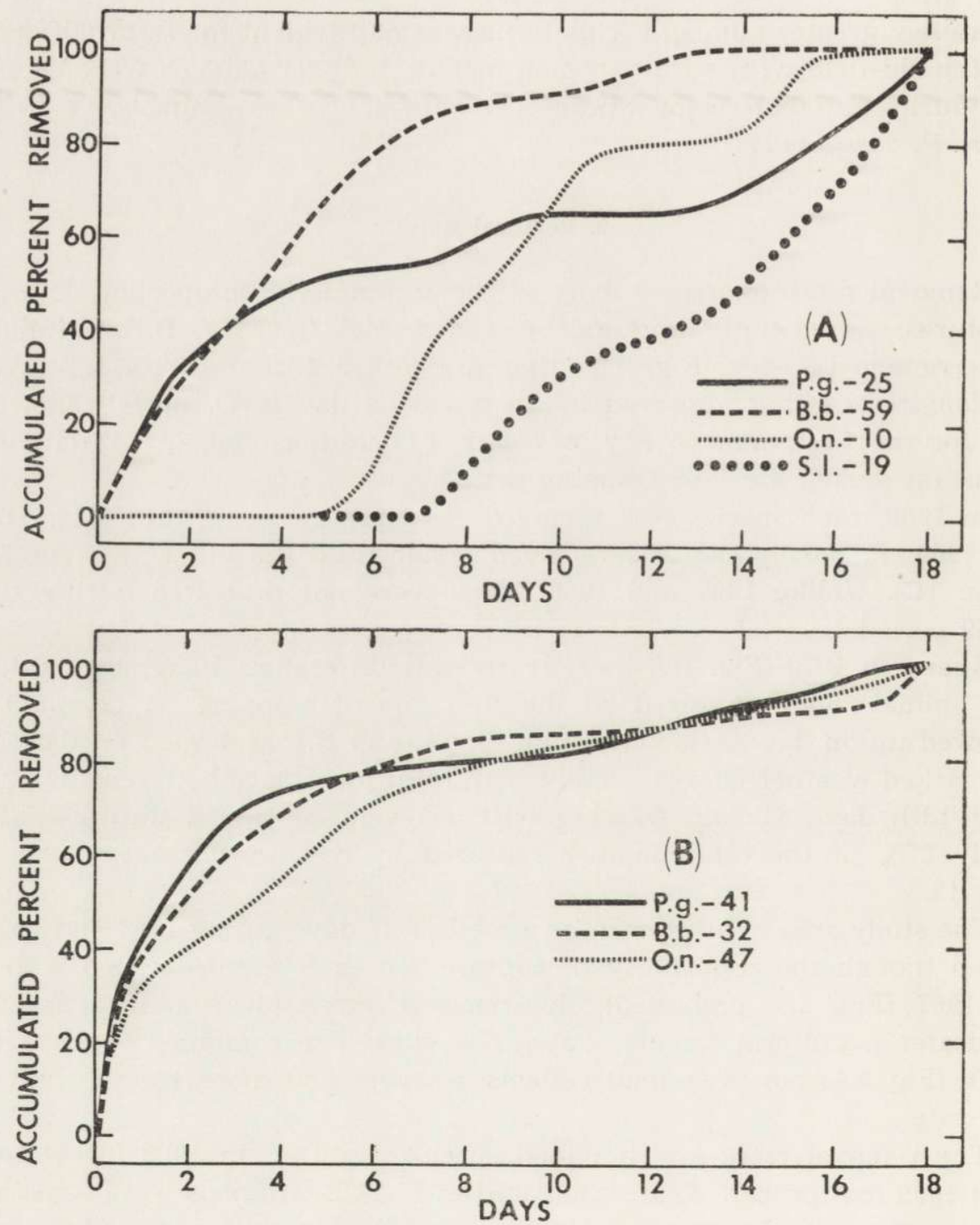

Fig. 1. Removal rates of different species of small mammals at different seasons. (A) Sept. - Oct., 1967 - prebaited; (B) July - Aug., 1968 - prebaited; (C) May June, 1969-not prebaited; (D) April - May, 1970 - not prebaited.

in similar habitats at the same time (Gentry, Smith \& Chelton, 1971a; K a u $\mathrm{fm}$ a $\mathrm{n}$ et al., 1971).

3. Length of trapping period: The length of each trapping period was not the same (Table 1), although comparisons could easily be made on an 18-day basis for all four periods. The additional nine days for the 1967 period added only one animal, or $5.9 \%$ of the total 60 animals 

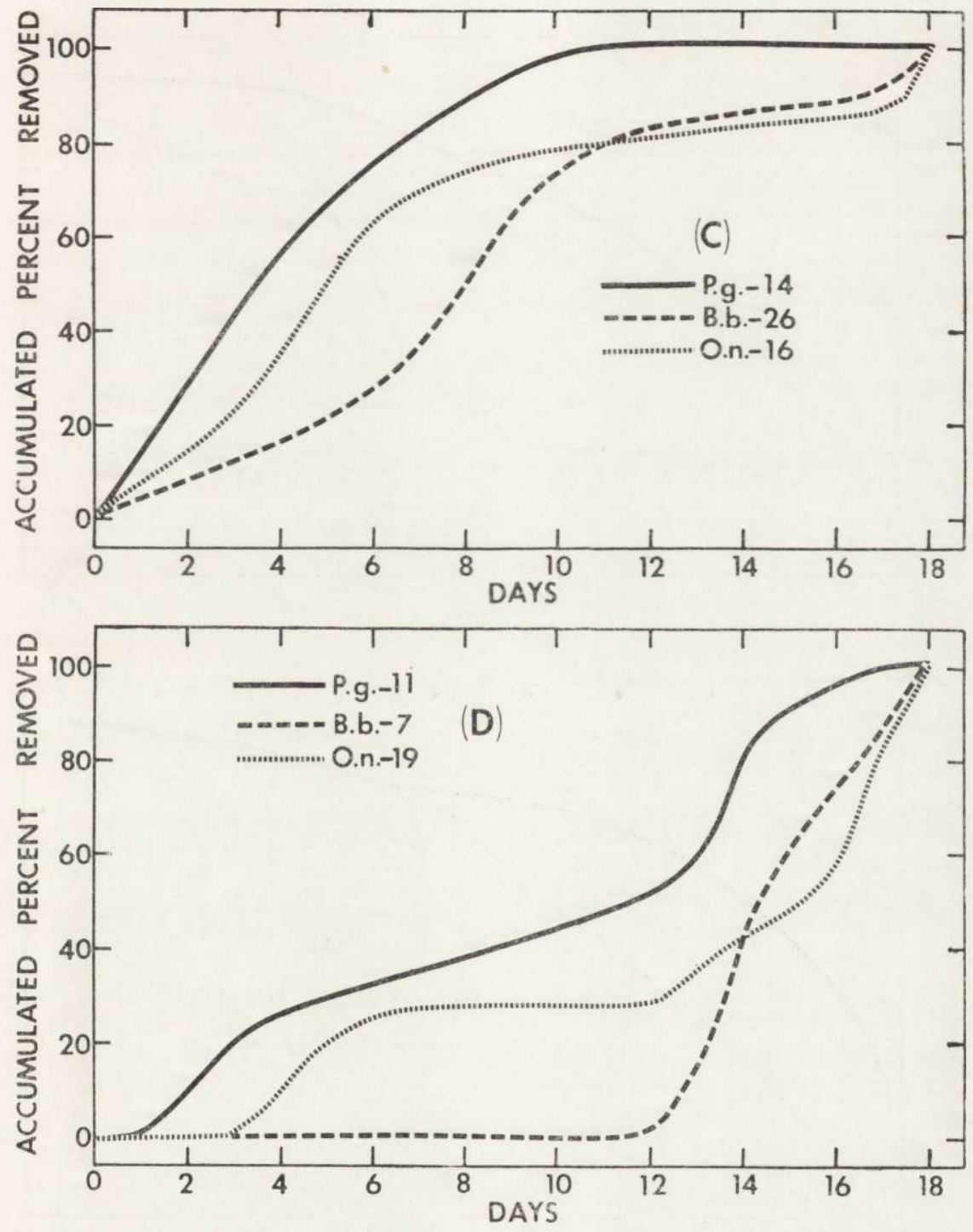

Fig. 1. Continued.

removed in 27 days. However, the additional nine days for the 1970 removal period added seven animals, or $26.9 \%$ of the total 26 animals removed in 27 days.

4. Movement: The degree of small mammal movement was not determined. Movement likely differed between removal periods since movements may be correlated with relative density and season ( $\mathrm{Brant}$, 1962; White, 1964; Van Vleck, 1969). Several investegators (A damczyk \& Ryszkowski, 1968; Tanton, 1969; Rysz- 

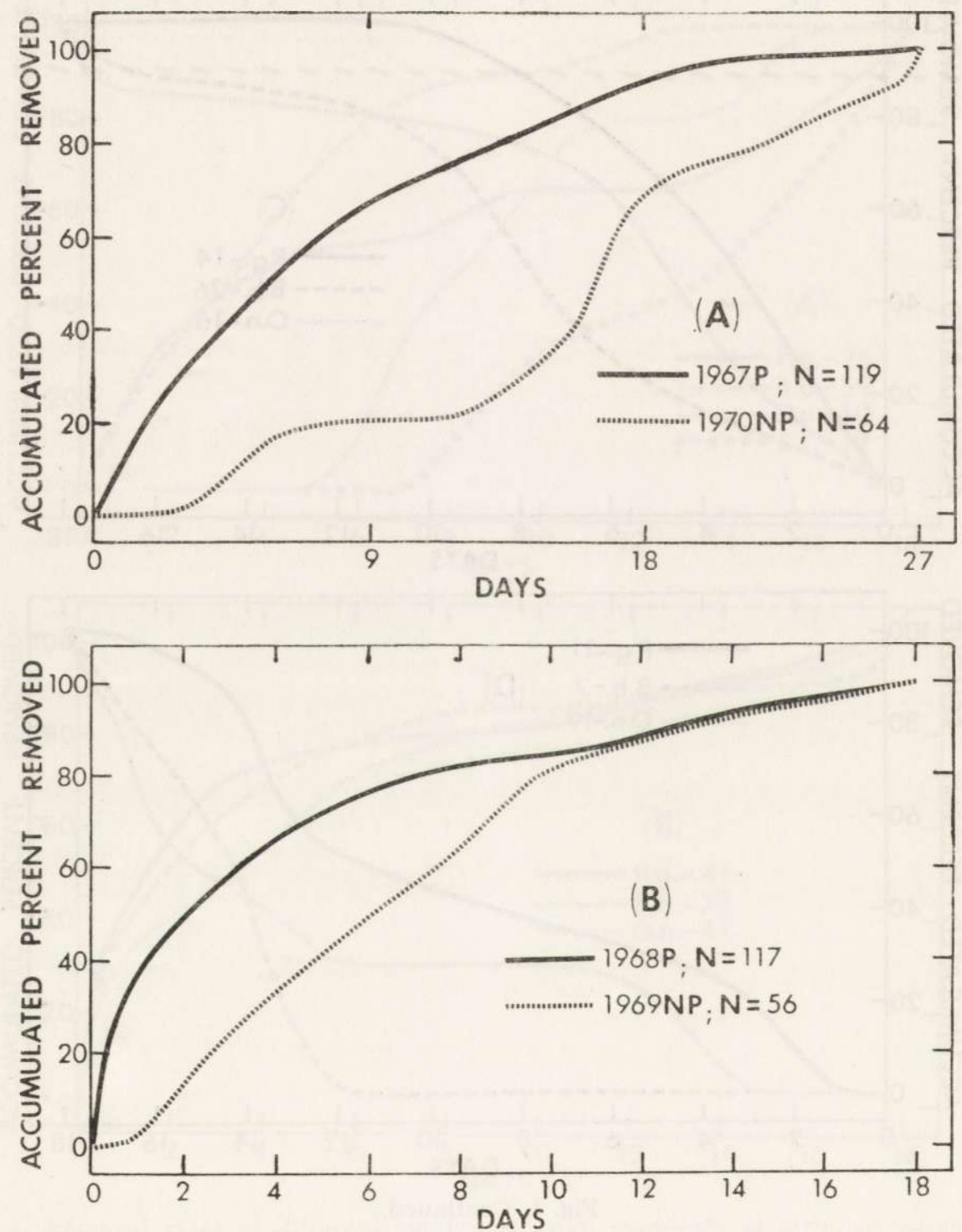

Fig. 2. Comparison of the removal rates of the small mammals captured during 1967 and 1970 (A) with the 1968 and 1969 (B) trapping periods. The small mammal species are: P. gossypinus, O. nuttalli, B. brevicauda, and $S$. longirostris. ( $\mathrm{P}=$ prebaited; $\mathrm{NP}=$ not prebaited).

kowski, 1971; Faust, Smith \& Wray, 1971; Gentry, $\mathrm{Smith} \&$ Beyers, 1971b have recently shown interest in small mammal movement patterns. The amount of movement in a small mammal population can influence the size of the area from which ani- 
mals are removed by trapping. Area is an essential variable in the calculation of absolute density.

\section{DISCUSSION}

It is obvious that certain factors can and do influence small mammal trapping results. Such biases cast doubts upon the accuracy of density estimates. The effect of these variables and their interactions is reflected in a change in the probability of capture. To circumvent this basic problem, the probability of capture may be assumed to be constant ( $\mathrm{H}$ a y $\mathrm{n}$ e, 1949). Prebaiting may be applied to remove the animals more quickly and thus reduce the effects of a changing probability of capture

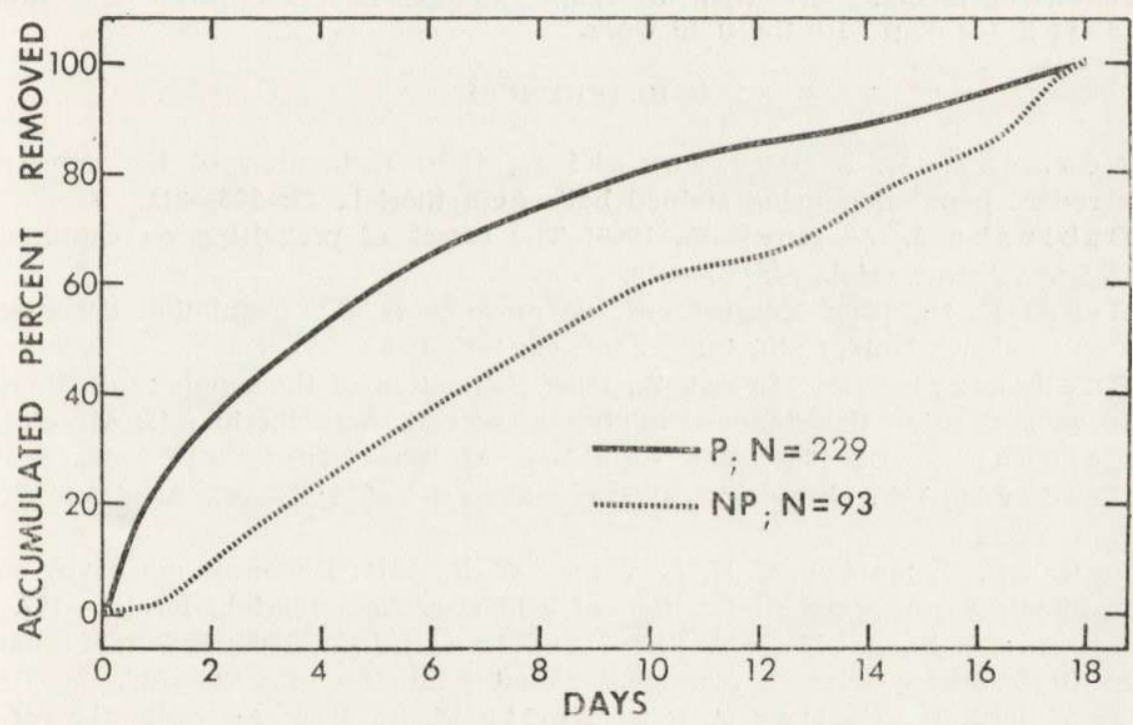

Fig. 3. Comparison of the removal rates of the small mammal captured at prebaited $(1967,1968)$ and not prebaited $(1969,1970)$ stations. $(P=$ prebaited; $N P=$ not prebaited.

(Grodziński et al., 1966). Prebaiting serves to reduce the bias due to variable probability of capture and tends to increase the removal rate (B a binska \& Bock, 1969), at least during the first days of removal. Prebaiting is essential if the linear regression method ( $\mathrm{H}$ a y $\mathrm{n} \mathrm{e}$, 1949 ) is used to estimate small mammal numbers (Grodziński et al., 1969).

Certain mathematical treatments may be applied to the data to correct for varying probability of capture (Janion, Ryszkowski \& Wierzbowska, 1968; Parr, Gaskell \& George, 1968). Many such mathematical treatments are themselves based on certain 
statistical assumptions. The end result is usually an estimate of the number of animals captured by traps on a grid or line.

To get a true density estimate, we must know the area from which the animals were removed. If varying conditions influenced removal rates, this should be reflected in the size of the area of effect. Thus, the obvious approach is to develop a way to measure the area of effect around a grid or census line. Such an approach has been adopted at the Savannah River Ecology Laboratory and methods have been developed to assess the area of effect created by removal trapping ( $\mathrm{K}$ a $\mathrm{u} \mathrm{f} \mathrm{m}$ a $\mathrm{n}$ et al., 1971; Gentry et al., 1971a; Smith, Blessing, Chelton, Gentry, Galley \& McGinnis, 1971).

Acknowledgements: We wish to thank Messrs. Beyers W ray and Ronald Blessing for help with the field work.

\section{REFERENCES}

1. Adamczyk K. \& Ryszkowski L., 1968: Estimation of the density of a rodent population using stained bait. Acta theriol., 13: 295-311.

2. Babińska J. \& Bock E., 1969: The effect of prebaiting on captures of rodents. Acta theriol., 14: 267-270.

3. Brant D. H., 1962: Measures of the movements and population densities of small rodents. Univ. Calif. Publ. Zool., 62: 105-184.

4. Buchalczyk T. \& Pucek Z., 1968: Estimation of the numbers of Microtus oeconomus using the standard minimum method. Acta theriol., 13: 461-482.

5. Calhoun J. B., 1964: The social use of space [In: M a yer W. \& Van Geld er R., Eds. »Physiological Mammalogy«] Vol. 1: 1-187. Academic Press, New York.

6. Faust B. F., Smith M. H. \& Wray W. B., 1971: Distances moved by small mammals as an apparent function of grid size. Acta theriol., 16: 161-177.

7. Gentry J. B., Golley F. B. \& McGinnih J. T., 1966: Effect of weather on the captures of small mammals. Amer. Midl. Nat., 75: 526-530.

8. Gentry J. B., Golley F. B. \& S mith M. H., 1968: An evaluation of the proposed International Biological Program census method for estimating small mammal populations. Acta theriol., 13: 313-327.

9. Gentry J. B., Smith M. H. \& Chelton J. G., 1971a: An evaluation of the octagon census method for estimating small mammal populations. Acta theriol., 16: 149-159.

10. Gentry J. B., Smith M. H. \& Beyers R. J., 1971b: Use of radioactively tagged bait to study movement patterns in small mammal populations. Ann. Zool. Fennici, 8: 17-21.

11. Grodziński W., Pucek Z. \& Ryszkowski L., 1966: Estimation of rodent numbers by means of prebaiting and intensive removal. Acta theriol., 11: $297-314$.

12. Hay ne D. W., 1949: Two methods for estimating population from trapping records. J. Mamm., 30: 399-411.

13. Janion M., Ryszkowski L. \& Wierzbowska T., 1968: Estimate of number of rodents with variable probability of capture. Acta theriol., 13: $285-293$. 


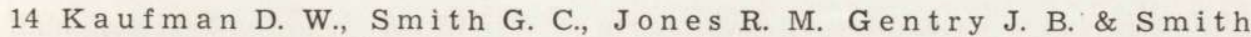
M. H., 1971: Use of assessment lines to estimate density of small mammals. Acta theriol., 16: 127-147.

15. Parr M. J., Gaskell T. J. \& George B. J., 1968: Capture-recapture methods of estimating animal numbers. J. Biol. Educ., 2: 95-117.

16. Pucek Z., 1969. Trap response and estimation of numbers of shrews in removal catches. Acta theriol., 14: 403-426.

17. Ryszkowski L., 1971: Estimates of small rodent density by use of coloured bait. Ann. Zool. Fennici, 8: 8-13.

18. Smith G. C., Ka ufman D. W., J ones R. M., Gentry J. B. \& Smith M. H., 1971: The relative effectiveness of two types of snap traps. Acta theriol., 16: $000-000$

19. Smith M. H., Blessing R., Chelton J. G., Gentry J. B., Golley F. B. \& M c Ginnis J. T., 1971: Determining density for small mammal populations using a grid and assessment lines. Acta theriol., 16: 105-125.

20. Tanton M. T., 1969: The estimation and biology of populations of the bank vole (Clethrionomys glareolus (Schr.)) and wood mouse (Apodemus sylvaticus (L.)) J. Animal Ecol., 38: 511-530.

21. White J. E., 1964: An index of the range of activity. Amer. Midl. Nat., 71: $369-373$.

22. Van Vleck D. B., 1969: Standardization of Microtus home range calculation. J. Mamm., 50: 69-80.

Accepted, March 15, 1971.

Savannah River Ecology Laboratory, SROO, P. O. Box A,

John B. GENTRY, Michael H. SMITH i Frank B. GOLLEY

\section{ROCZNE WAHANIA W POPULACJACH DROBNYCH SSAKÓW}

\section{W LESIE LISCIASTYM}

\section{Streszczenie}

W kompleksie dojrzałego lasu liściastego w pobliżu Aiken (Południowa Karolina, USA) założono powierzchnię Standard Minimum, czynne raz w roku w latach 1967-1970 (Tabela 1). Pułapki były zanęcane w 1967 i 1968 r., podczas gdy w 1969 i 1970 r. przynęty nie stosowano. Odłowy prowadzono w ciągu 18 dni w latach 1968 i 1969 i 27 dni w latach 1967 i 1970.

Populacje drobnych ssaków w tym lesie składały się z: Peromyscus gossypinus, (Le Conte, 1853), Blarina brevicauda, (S a y, 1823), Ochrotomys nuttalli (H a r l a n, 1823) i Sorex longirostris (B a c h m a n, 1837).

W każdym z okresów połowów chwytano więcej samców P. gossypinus (Tabela 3). To samo dotyczy O. nuttalli w sezonach złowień w 1968 i 1969 r.; w 1967 i 1970 r., jednak samców było znacznie więcej niż samic. Odłowy samic były większe dla 
B. brevicauda w każdym roku, z wyjątkiem 1968 r. W 1967 r. łowiono więcej samic S. longirostris niż samców w stosunku jak $3: 1$.

Udział zwierząt łowionych w nizinnym, bagiennym lesie liściastym i wyżynnym lesie liściastym w $1968 \mathrm{r}$. nie odbiegał znacznie od stosunku jak 1:1 (Tabele 4 i 5). $\mathrm{Z}$ drugiej strony, analogiczne porównanie dla 1967, 1969 i 1970 r. zbliżało się raczej do stosunku jak $3: 1$. Mimo pewnej zmienności pomiędzy latami, wszystkie cztery gatunki preferowały nizinne środowisko bagiennego lasu liściastego (Tabela 4).

Tempo wyłowu wykazywało zmienność w czasie i pomiędzy gatunkami. W $1967 \mathrm{r}$. osobniki $B$. brevicauda były wyławiane w najszybszym tempie (Ryc. 1). Osobniki $P$. gossypinus były usuwane $\mathrm{w}$ najszybszym tempie podczas trzech kolejnych okresów odłowów. W 1967 r. (Ryc. 1) S. longirostris znalazła się po raz pierwszy w pulapkach 6 dnia; $O$. nuttalli ujawnił się po raz pierwszy 9 dnia. W $1970 \mathrm{r}$. nie zanotowano żadnych złowień pierwszego dnia (Ryc. 4). P. gossypinus został po raz pierwszy złowiony 2 dnia, O. nuttalli -3 dnia a $B$. brevicauda -13 dnia. Trzynastego dnia zwiększyło się tempo wyłowu wszystkich gatunków. Pomiędzy 12 a 13 dniem nastąpiła znaczna zmiana pogody (pochmurno i deszczowo).

Skutki wstępnego zanęcania ilustruje Ryc. 7. Tempo wyłowu w latach 1967 i 1968 było wyższe niż w odpowiednich okresach 1969 i 1970 r. Innymi ezynnikami wpływającymi na tempo wyłowu były: sezon, względna liczebność ssaków, długość okresu odłowiania oraz zmienne warunki pogody.

Po to, by otrzymać prawdziwe oszacowanie zagęszczenia, musimy znać powierzchnię, z której usunięto zwierzęta. Jeśli zmienne warunki wpływają na tempo wyłowu, powinno to znaleźć odzwierciedlenie w wielkości obszaru wpływu. A zatem, należy opracować sposób pomiaru obszaru, oddziaływanie podziałki lub linii inwentaryzacyjnej. Takie podejście zostało przyjęte przez kilku badaczy w Pracowni Ekologicznej Savannah River (Ka ufman et al., 1971; Gentry et al., 1971; S mith et al., 1971). 